INTERNATIONAL JOURNAL OF MULTIDISCIPLINARY RESEARCH AND ANALYSIS

ISSN(print): 2643-9840, ISSN(online): 2643-9875

Volume 04 Issue 12 December 2021

DOI: 10.47191/ijmra/v4-i12-07, Impact Factor: 6.072

Page No.- 1809-1819

\title{
The Effect of Factors on Operational Efficiency and the Relationship between Operational Efficiency and Solvency of Logistics Joint- Stock Companies
}

\author{
Long Thanh Le ${ }^{1}$, Ha Thi Thu Nguyen ${ }^{2}$ \\ ${ }^{1,2}$ Advanced Education Program Institute, National Economics University
}

ABSTRACT: Operational Efficiency (OE) and solvency play an important role in the success of any enterprises. Therefore, studying the relationship between $\mathrm{OE}$ and solvency needs to be taken comprehensively and continuously in order to find out long -term solutions for increasing business effectiveness. This paper examines the determinants of $\mathrm{OE}$ and the relationship between $\mathrm{OE}$ and solvency of the logistics joint-stock companies (JSCS) listed on the Vietnam Stock market with answers for the above - mentioned issues. This study mainly investigates 30 listed logistics firms from 2014 to 2018. The findings of this study suggested that the relationship between $\mathrm{OE}$ and solvency of logistics JSCs is inversely correlation.

KEY WORDS: Operational Efficiency, Solvency, Logistics JSCs.

\section{INTRODUCTION}

In the world's current trend, logistics has become an economic industry - an essential service not only in Vietnam but also in the world. According to Council of Supply Chain Management Professionals (CSCMP), logistics which is an important sector in the overall structure of national economy, can bridge the gaps among other economic sectors, as well as promote the overall national economy. Therefore, this industry can solve the problem of optimizing unnecessary costs. Not falling out of this trend, top logistics enterprises in Vietnam have equipped themselves with sustainable resources in order to adapt to this change and serve full potential domestic market. In this context, managers need to understand the financial structure of their businesses to make appropriate adjustments and decisions to ensure operational efficiency and enhance development. However, Vietnamese researchers have put too much emphasis on capital structure (the relationship between debt and equity) and they have only paid little attention to solvency, which is also a very important issue in financial management. According to statistics of Hanoi Stock Exchange (HNX) and Ho Chi Minh City Stock Exchange (HOSE), the amount of capital listed on the trading floor of Vietnamese logistics enterprises is still moderate. There exist significant gaps in the amount of limited capital among internal enterprises in the same industry. According to the Vietnam Business Association, there are 1,200 logistics enterprises operating in the public sector. Apart from state-owned enterprises, most of them are small and medium-sized companies with limited resources. Therefore, these private companies cannot guarantee the ability to pay their own debts and ensure operational efficiency at the same time. This current situation generates deep challenges in management, investment, and production. All of these give rise to challenges for logistics JSCs in their business operation, in which, OE and solvency are not exceptional. The link between OE with the solvency of these companies is still controversial. Up to now, there is generally hardly any domestic concrete research to clarify the relationship between OE and solvency of enterprises and especially among logistics JSCS in Vietnam. As a result, this article will concentrate on identifying determinants of OE and the tie between OE and solvency of logistics JSCs so as to give a supported clue for this problem.

\section{LITERATURE REVIEW AND HYPOTHESIS}

There are many concepts of Operational Efficiency (OE) from different researchers both domestically and internationally and below are some typical ones. Operational efficiency can be formally defined as the ability of an enterprise to ensure the high quality of its products and services while delivering products or services to its customers in the most cost-effective manner possible (Beal, 2016). In addition, according to Matthew Burrows (2016), OE is not just about reducing costs; other business objectives 


\section{The Effect of Factors on Operational Efficiency and the Relationship between Operational Efficiency and Solvency of Logistics Joint-Stock Companies}

including service quality, still have to be achieved in order to keep existing customers and maintain high revenue. Also, the study of Dennis Hartman (2016) pointed out a method of measuring OE by evaluating how well a business managed its resources and utilized them to generate profits. A theory which was developed by Neil Kokemuller (2016) focused on OE in terms of encompassing several strategies and techniques used to accomplish the basic goal of delivering quality goods to customers in the most cost- effective and timely manner; and on OE involving performing similar activities in more efficient ways than their competitors. Moreover, Subha Varadan (2016) proposed that "OE is a critical system that can keep a company in business or close it down". In terms of typical domestic researches, Nguyen Van Cong (2019) pointed out that the OE of a company reflected operation results that a company possibly got when it used its input for business operation. Basically, OE is an indicator of the efficiency of using the input elements of business operation and solvency.

In terms of measuring OE, the study of Bernstein (1988) identified that OE which presented firm performance can be evaluated by financial ratios such as solvency, capital structure, profitability, and turnover. In addition, Feng (2000) did also take financial ratios into consideration on carrying out firms' performance evaluation process for airlines by using grey relation analysis and TOPSIS method to overcome the problem of small samples and outranking of airlines. According to Hobarth (2006), he showed the correlation between financial indicators and OE of listed firms in the USA for a19-year period by using 17 financial indicators and 3 variables to measure firm's performance, namely market performance (measured by changes in stock market value), cash flow performance (solvency), and profitability (ROI). Sandstrom (2007) presented a historical review and some pragmatic solutions to Solvency. More specifically he discussed four fundamental issues needed for constructing solvency systems, i.e. valuation of assets and liabilities, risk margin for uncertainty in liabilities and assets and risk measures and modeling (risk categories, risk mitigation, diversification, etc.).

Regarding solvency, there is an array of different definitions. First of all, according to Pentikäinen, T. (1952), the definition of solvency was the difference between assets and liabilities. Benjamin (1977) refered to the Oxford Dictionary, which defined solvency as "having enough money to meet all liabilities". Developing the theory of Pentikäinen, T, Jackson et al. (2002) defined a firm's solvency as when its total assets were higher than current liabilities. Langiemer (2004), solvency measured the amount of debt and other cost obligations used in a company's business compared to the amount of equity invested in an enterprise. Ibenta (2005) argued that solvency was a firm's ability to meet capital needs.

Scale of company: Usually, large-scale businesses will have incessant and sustainable resources. With financial strength these businesses will easily minimize input costs and increase output efficiency. Research by Gleason, L. K Mathur and I.Math ur (2000), Onaolapo and Kajola (2010) showed that firms' size had a positive and significant impact on business performance, i.e.the bigger a business is, the efficiency it could generate. However, according to the results of other studies from such researchers as Mudambi and Nicosia (1998), Lauterbach and Vaninsky (1999), Durand and Coeuderoy (2001), Tzelepis and Skuras (2004), Zeitun and Tian (2007), the scale had positive impact but not significant on business performance of the enterprise.

\section{H1: Scale of company has a positive impact on Operational Efficiency}

Degree of financial independence: The degree of financial independence is presented by the proportion of owner equity out of total equity (abbreviated as ER). The more debts a company owed, the lower degree of financial independence of this company is. According to the theory of Modigliani and Miller, when a business starts to borrow, the business will have advantages of tax shield. The low cost of debt combined with the tax shield advantage will lead to a decrease in total cost. Therefore, business performance is enhanced. Specifically, if the companies kept the degree of financial independence at a low level, its OE would increase. In contrast, the empirical research results of Zeitun and Tian (2007), Neil Nagy (2009); Fozia Memon, Niaz Ahmed Bhutto, Ghulam Abbaas (2012) showed that debt ratio had a negative and significant effect on business performance of the enterprise.

\section{H2: Degree of financial independence has a positive impact on Operational Efficiency}

Total assets: Empirical research results of Rami Zeitun and Gary Gang Tian (2007); Onaolapo and Kajola (2010); Marian Siminica, Daniel Circiumaru, Dalia Simion (2011); Fozia Memon, Niaz Ahmed Bhutto and Ghulam Abbas (2012) showed that total assets were significantly negative impacts on business performance of the enterprise. According to the research of Marian Siminica, Daniel Circiumaru, Dalia Simion (2011), total assets also had a positive and significant effect on the OE of the company.

\section{H3: Total assets has a positive impact on Operational Efficiency}

Sales: The revenue will reflect the capacity of sales activities. An increase in goods sold, can positively affect business performance of a business. The study of Nguyen Quoc Nghi (2010) proved that there existed a direct correlation between total sales and $O E$.

H4: Total sales has a positive impact on Operational Efficiency 
The Effect of Factors on Operational Efficiency and the Relationship between Operational Efficiency and Solvency of Logistics Joint-Stock Companies

\section{The relationship between $O E$ and solvency}

After considering different concepts of $\mathrm{OE}$ and solvency, one question has appeared: Is there any relationships between them? In fact, this topic has not attracted many studies from domestic researchers except for some foreign ones.

On the one hand, there exists a positive relationship between OE and solvency.Lambery and Valming (2009) evaluated and compared the solvency management of companies listed on the Stockholm Stock Exchange over two times to see how solvency's changes affecting firms' performance. The results showed that solvency maintenance strategies did not have any significant impact on operational efficiency.

A study of Victor Chukwunwieke (2014) determined the relationship between quick ratio and profitability ratios of listed companies on the Nigerian stock exchange NSE. The author concluded that there was a positive correlation between quick ratio and profitability ratios.

Rafid Hamad (2016) conducted an assessment of the relationship between solvency and performance of Standard Chartered Bank in Pakistan. This study showed that there was a positive relationship between solvency and OE of enterprises.

On the other hand, some researchers announced a negative correlation between OE and solvency. Jennifer Muthio Kyule (2015) conducted a research on the relationship of OE and solvency for financial activities of listed companies on Nairobi stock exchange, Kenya. The dependent variable presented for OE was ROA, while the independent variables were: solvency, liquidity, financial leverage, minimum capital adequacy ratio, and size of businesses (total assets). The author concluded that solvency was negatively correlated with ROA which presented for OE.

Evengi Raykov (2017) explored a trade-off between solvency and profitability in the event of financial crisis. Analysis data were collected by the authors from quarterly financial reports of 20 companies selected from different economies in the Bulgarian economy during 2007-2015. Through empirical testings of many hypotheses, the work came to a conclusion that during the 2007 crisis, financial managers successfully separated profits from payables when the correlation between them was negative.

H5: Operational efficiency has a significant and positive relationship on Solvency

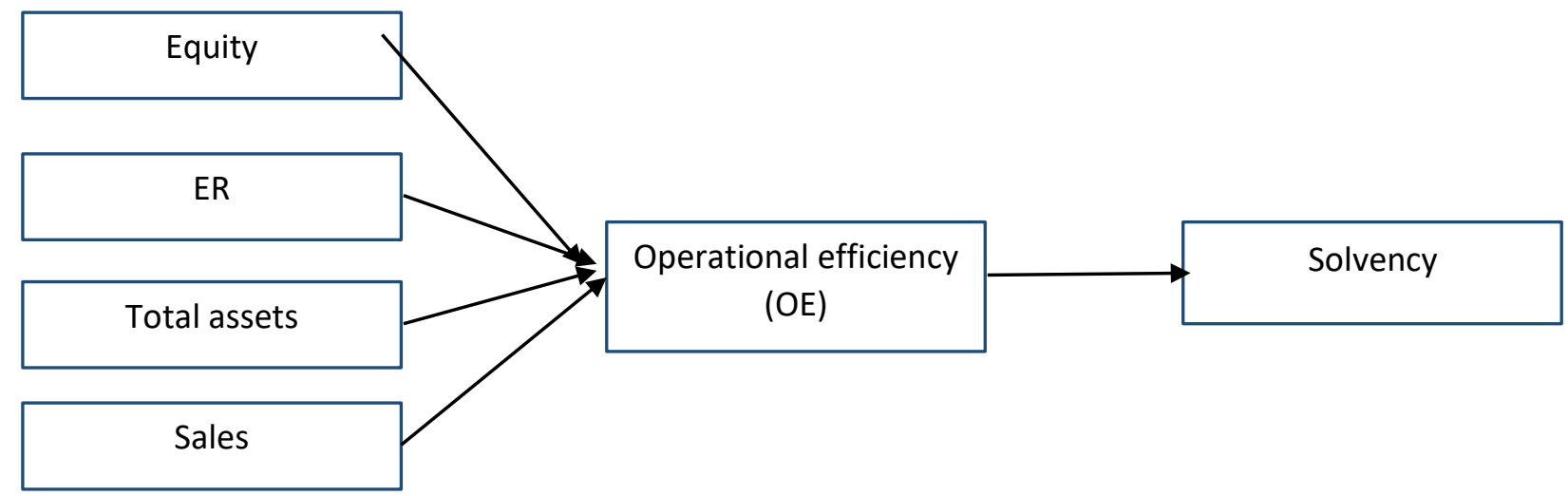

Fig 1. Conceptual Model

\section{METHODOLOGY}

\section{Evaluation indicators}

Operational Efficiency

In a study on the valuation of operating efficiency in Egypt firms, Armer, Mostafa and Eldomiaty (2011) found asset quality, capital adequacy, credit risk and liquidity as major determinants of OE in highly competitive companies. Based on the results found by Armer, Mustapha and Eldomiaty (2011) and a theory developed by Hobarth (2006) about using financial ratios to evaluate OE, Nguyen Van Cong (2019) measured OE via:

- Total asset turnover (TAT) presented for asset quality.

- $\quad$ Equity turnover (ET) presented for capital adequacy.

- $\quad$ Equity Ratio (ER) presented for liquidity.

Solvency

The dimensions' choice was influenced by the work of Nguyen Van Cong (2019).Based on this scale, Solvency can be measured via two ratios:

- $\quad$ Overall Ratios presented for the ability to repay all companies' debts in overall.

- $\quad$ Quick Ratios presented for the ability to secure short-term debts. 


\section{The Effect of Factors on Operational Efficiency and the Relationship between Operational Efficiency and Solvency of Logistics Joint-Stock Companies}

Data

Data used in this study was collected from financial statements, annual reports of logistic firms listed in two major State Securities Commission of Vietnam: HNX and HOSE for the period from 2014 to 2018. These data were audited by the world famous auditing firms (e.g.: E\&Y, KPMG, A\&C...) and downloaded from the reliable websites of the HNX and the HOSE in this survey.

These logistic firms with their data lead to a research sample with 150 observations during this period. In this case, the above-mentioned data were transferred into Excel and encoded as variables. After that, they become inputs for running regression

\section{Method}

In order to examine the $\mathrm{OE}$ of researched enterprises, there are six variables used as follows. Two dependent variables which present for OE are Equity Turnover (ET) and Total Assets Turnover (TAT) and four other independent variables: Assets (presenting total assets of a company), Equity (presenting scale of a company), Equity Ratio $\left(\mathrm{ER}=\frac{\text { Owners equity }}{\text { Total assets }}\right.$, presenting liquidity of companies) and Sales (presenting the result of selling process). After that, in order to measure the solvency of listed logistics firms, there are two dependent variables: Quick ratio (QUICK $=\frac{\text { Current assets }- \text { inventory }}{\text { Curent liabilities }}$ ) and Overall ratio (OVERALL $=$ $\frac{\text { Total assets }}{\text { Total liabilities }}$ ) three other controlling variables, including TAT, ER, and ET.

The study applies both qualitative and quantitative approaches. For a qualitative approach, the study takes a comparative and analytical method in order to assess the current situation of OE and solvency as well as detect the relationship between them. Theory frame is based on a fundamental base about a system of ratios which reflect the OE (ET and TAT) and Solvency (QUICK and OVERALL) of a company.

In addition, in order to strengthen the reliability of this study's result, this paper also uses a quantitative approach by running a regression model of Ordinary Least Square (OLS) with the above-mentioned variables. The OLS's first aim is to investigate how many factors impact OE and what they are. The second purpose is to forecast the link between OE and solvency. This paper uses the statistic software Stata 15 to run the regression to answer these questions.

The use of both qualitative and quantitative approaches aims to strengthen the reliability of the analyses and judgments because it collects evidence from different sources and creates a multi-directional vision of an issue. This combination also helps the result to satisfy planned purposes better and answer the research questions clearly as well as lead to conclusions which ensure a scientific base and feasibility.

\section{RESULT}

There are many listed firms providing logistic services in Vietnam and their stocks are listed on the two main securities exchanges of Vietnam, the HOSE and HNX. In order to have an overview of financial situation of all firms in this industry, this paper has selected listed firms on both HNX and HOSE.

There are thirty Logistics JSCs which were divided equally in both HNX and HOSE (14 firms listed on the HNX and 16 firms listed on the HOSE). Of these, Vietnam Airlines corporation (HVN) has the highest authorized-capital with nearly 82,000 billion Vietnam Dong (VND), which is nearly two times bigger than the second highest authorized-capital (VJC-36,000 billion VND and three times bigger than the HNX highest authorized-capital (PHP), while the smallest authorized-capital is PRC with only 12 billion VND. Concretely, eight companies including CDN, DL1, PHP, VJC, GMD, HVN, PVT, and VOS have their scale of capital from over 1000 billion VND. In this paper, all surveyed firms shall be mentioned by their coded stocks instead of their names.

\section{Operational efficiency}

Firstly, a company's capital scale is not directly proportional to its OE. More clearly, despite its highest capital scale at nearly 82,000 billion VND, circulating turnover of total assets in HVN only ranks kin the eleventh place at 0.75 times, which is lower than the lowest authorized-capital firm VNLas shown in Table 1.

This conclusion is also strengthened when VJC stands in the second place of capital scale (at 36,000 billion VND) but at the tenth place of OE in terms of total assets turnover (TAT). On the other hand, in this period, VNL and PRC have the lowest capital scale but express its graduation in circulating turnover of total assets among the first and can be seen clearly in Table 1.

Table 1. Circulating turnover of total assets (TAT).

\begin{tabular}{lrrrrrr}
\hline JSCs & \multicolumn{2}{c}{$\mathbf{2 0 1 4}$} & \multicolumn{1}{c}{$\mathbf{2 0 1 5}$} & \multicolumn{2}{c}{$\mathbf{2 0 1 6}$} & \multicolumn{2}{c}{$\mathbf{2 0 1 7}$} & \multicolumn{1}{c}{$\mathbf{2 0 1 8}$} & Average \\
\hline 01.VNL & 2.706 & 2.451 & 2.231 & 2.567 & 2.851 & 2.561 \\
02.PRC & 3.174 & 2.371 & 1.922 & 1.846 & 1.598 & 2.182
\end{tabular}


The Effect of Factors on Operational Efficiency and the Relationship between Operational Efficiency and Solvency of Logistics Joint-Stock Companies

\begin{tabular}{|c|c|c|c|c|c|c|}
\hline 03.GSP & 1.073 & 1.371 & 2.407 & 2.572 & 2.579 & 2.000 \\
\hline 04.STG & 3.959 & 2.144 & 0.602 & 0.499 & 0.554 & 1.552 \\
\hline 05.SFI & 1.748 & 1.363 & 1.277 & 1.493 & 1.680 & 1.512 \\
\hline 06.CAG & 0.627 & 0.571 & 4.995 & 0.431 & 0.435 & 1.412 \\
\hline 07.VNS & 1.676 & 1.604 & 1.487 & 0.945 & 0.705 & 1.283 \\
\hline 08.VJC & 1.305 & 1.117 & 1.037 & 0.950 & 1.029 & 1.088 \\
\hline 09.MAC & 1.002 & 0.858 & 0.851 & 0.832 & 0.748 & 0.858 \\
\hline 10.TTZ & 0.389 & 0.777 & 0.971 & 0.358 & 1.720 & 0.843 \\
\hline 11.HVN & 0.865 & 0.532 & 0.663 & 0.762 & 0.926 & 0.750 \\
\hline 12.NAP & 0.644 & 0.511 & 0.624 & 0.641 & 0.682 & 0.620 \\
\hline 13.BSC & 0.591 & 0.496 & 0.961 & 0.495 & 0.528 & 0.614 \\
\hline 14.HHG & 0.583 & 0.613 & 0.602 & 0.604 & 0.469 & 0.574 \\
\hline 15.HTV & 0.587 & 0.590 & 0.524 & 0.495 & 0.571 & 0.553 \\
\hline 16.VGP & 1.031 & 1.397 & 0.234 & 0.104 & 0.000 & 0.553 \\
\hline 17. $\mathrm{HAH}$ & 0.568 & 0.509 & 0.463 & 0.525 & 0.505 & 0.514 \\
\hline 18.CDN & 0.226 & 0.505 & 0.558 & 0.516 & 0.477 & 0.456 \\
\hline 19.VSC & 0.574 & 0.512 & 0.337 & 0.334 & 0.391 & 0.430 \\
\hline 20.TMS & 0.506 & 0.461 & 0.423 & 0.343 & 0.300 & 0.407 \\
\hline 21.CLL & 0.453 & 0.440 & 0.414 & 0.391 & 0.316 & 0.403 \\
\hline 22.VOS & 0.369 & 0.314 & 0.260 & 0.399 & 0.450 & 0.358 \\
\hline 23.PVT & 0.283 & 0.338 & 0.349 & 0.370 & 0.438 & 0.356 \\
\hline 24.DL1 & 0.452 & 0.378 & 0.235 & 0.046 & 0.019 & 0.226 \\
\hline 25.PHP & 0.155 & 0.255 & 0.251 & 0.227 & 0.218 & 0.221 \\
\hline 26.ACV & 0.211 & 0.255 & 0.000 & 0.289 & 0.316 & 0.214 \\
\hline 27.HMH & 0.203 & 0.283 & 0.164 & 0.150 & 0.136 & 0.187 \\
\hline 28.PGT & 0.261 & 0.072 & 0.043 & 0.043 & 0.239 & 0.131 \\
\hline 29.GMD & 0.161 & 0.152 & 0.139 & 0.092 & 0.033 & 0.115 \\
\hline 30.TCO & 0.124 & 0.088 & 0.057 & 0.059 & 0.060 & 0.078 \\
\hline
\end{tabular}

From the above analysis, it can be said that a big capital scale is a convenient condition for a company to increase its OE but whether a company is able to explore this advantage or not, it is quite a different case.

To strengthen the founded result, our research team uses statistical software STATA 15 to model a regression with the least squares regression method (OLS). After running model with the dependent variable of (TAT) as well as the three independent variables including Equity, ER and Sales (Independent variables are under logarithm), the results are expressed in Table 2.

Table 2. Regression TAT with Equity, ER and Sales

- reg tat er logequity logsales

\begin{tabular}{|c|c|c|c|}
\hline Source & SS & $d f$ & MS \\
\hline Model & 63.4640536 & 3 & 21.1546845 \\
\hline Residual & 31.6805086 & 146 & .216989785 \\
\hline Total & 95.1445622 & 149 & .638554109 \\
\hline
\end{tabular}

$\begin{array}{ll}\text { Number of obs } & = \\ \mathrm{F}(3,146) & = \\ \text { Prob }>\mathrm{F} & = \\ \text { R-squared } & = \\ \text { Adj R-squared } & = \\ \text { Root MSE } & =\end{array}$

\begin{tabular}{r|rrrrrr}
\hline tat & Coef. & Std. Err. & $t$ & P >lt & [95\% Conf. Interval] \\
\hline er & 1.569933 & .1960385 & 8.01 & 0.000 & 1.182493 & 1.957372 \\
logequity & -.696774 & .0428851 & -16.25 & 0.000 & -.7815297 & -.6120183 \\
logsales & .6702494 & .0404042 & 16.59 & 0.000 & .5903968 & .7501021 \\
_cons & .1958264 & .2684158 & 0.73 & 0.467 & -.3346559 & .7263087 \\
\hline
\end{tabular}



of Logistics Joint-Stock Companies

$$
\Rightarrow \quad \text { TAT }=0.20+1.57 * \text { ER }-0.70 * \log (\text { Equity })+0.67 * \log \text { (Sales) }
$$

From the above-mentioned results, it can be seen that independent variables of Sales and the ER maintain direct proportion with TAT and have at least 99\% statistical meaning. This explains that enterprises with a larger proportion of equity accompanied with higher revenue from sales of goods and services will have significant increases in their OE. In other words, the bigger the companies are, the larger their $\mathrm{OE}$ is and vice versa. This result is consistent with the initial judgment of the group.

Secondly, logistics firms' degree of financial independence is not directly proportional to their OE. The percentage of owners' equity in total capital (ER) is the most important ratio to express a company's degree of financial independence. Again, PRC and VNL are still leading companies in circulating turnover of owners' equity at 4,827 and 4,578 times respectively while these firm's percentage of owners' equity is only with its arithmetical mean of $20 \%$ during five years.

DL1is an enterprise that has the lowest circulating turnover of owners' equity (ET) with its arithmetical mean for the surveyed period of 0.255 times only. This can be expressed in Table 3.

Table 3. Circulating turnover of total equity (ET).

\begin{tabular}{|c|c|c|c|c|c|c|}
\hline JSCs & 2014 & 2015 & 2016 & 2017 & 2018 & Average \\
\hline 01.VJC & 9.022 & 8.748 & 6.801 & 5.174 & 5.673 & 7.083 \\
\hline 02.PRC & 6.563 & 5.200 & 4.578 & 4.243 & 3.551 & 4.827 \\
\hline 03.VNL & 4.518 & 4.588 & 4.168 & 4.619 & 4.996 & 4.578 \\
\hline 04.HVN & 5.340 & 3.166 & 3.919 & 3.814 & 4.020 & 4.052 \\
\hline 05.STG & 6.040 & 6.232 & 1.345 & 0.847 & 0.779 & 3.048 \\
\hline 06.GSP & 1.302 & 1.654 & 3.060 & 3.380 & 3.918 & 2.663 \\
\hline 07.VNS & 2.991 & 3.032 & 2.945 & 1.745 & 1.152 & 2.373 \\
\hline 08.SFI & 2.383 & 1.749 & 1.628 & 1.938 & 2.160 & 1.972 \\
\hline 09.VOS & 1.522 & 1.337 & 1.428 & 2.581 & 2.648 & 1.903 \\
\hline 10.CAG & 0.668 & 0.615 & 5.374 & 0.456 & 0.725 & 1.568 \\
\hline 11.MAC & 1.434 & 1.157 & 1.094 & 1.093 & 0.987 & 1.153 \\
\hline 12.TTZ & 0.531 & 1.051 & 1.309 & 0.454 & 2.065 & 1.082 \\
\hline 13.HHG & 1.235 & 1.090 & 1.027 & 1.011 & 0.740 & 1.020 \\
\hline 14.VGP & 1.625 & 1.617 & 0.245 & 1.188 & 0.000 & 0.935 \\
\hline 15.BSC & 0.747 & 0.654 & 1.251 & 0.624 & 0.650 & 0.785 \\
\hline 16. $\mathrm{HAH}$ & 0.850 & 0.864 & 0.786 & 0.752 & 0.619 & 0.775 \\
\hline 17.PVT & 0.703 & 0.761 & 0.716 & 0.708 & 0.839 & 0.745 \\
\hline 18.NAP & 0.775 & 0.600 & 0.709 & 0.704 & 0.706 & 0.699 \\
\hline 19.HTV & 0.760 & 0.700 & 0.588 & 0.568 & 0.675 & 0.658 \\
\hline 20.TMS & 0.720 & 0.704 & 0.717 & 0.577 & 0.508 & 0.645 \\
\hline 21.CDN & 0.325 & 0.654 & 0.696 & 0.711 & 0.663 & 0.610 \\
\hline 22.VSC & 0.689 & 0.606 & 0.386 & 0.370 & 0.427 & 0.495 \\
\hline 23.CLL & 0.614 & 0.576 & 0.508 & 0.432 & 0.328 & 0.492 \\
\hline 24.ACV & 0.434 & 0.552 & 0.000 & 0.535 & 0.562 & 0.416 \\
\hline 25.PHP & 0.203 & 0.348 & 0.343 & 0.292 & 0.285 & 0.294 \\
\hline 26.DL1 & 0.522 & 0.440 & 0.247 & 0.047 & 0.019 & 0.255 \\
\hline 27. HMH & 0.224 & 0.295 & 0.173 & 0.157 & 0.140 & 0.198 \\
\hline 28.GMD & 0.215 & 0.205 & 0.196 & 0.122 & 0.041 & 0.156 \\
\hline 29.PGT & 0.268 & 0.073 & 0.043 & 0.044 & 0.282 & 0.142 \\
\hline 30.TCO & 0.133 & 0.091 & 0.060 & 0.063 & 0.064 & 0.082 \\
\hline
\end{tabular}

To strengthen the founded result, our research team uses statistical software STATA 15 to model regression with the least squares regression method (OLS). After running model with dependent variable of (ET) as well as three independent variables including Asset, ER, and Sales (Independent variables are under logarithm), the results are expressed in Table 4. 
The Effect of Factors on Operational Efficiency and the Relationship between Operational Efficiency and Solvency of Logistics Joint-Stock Companies

Table 4. Regression ET with Asset, ER and Sales

- reg et er logasset logsales

\begin{tabular}{|c|c|c|c|c|c|c|}
\hline Source & SS & $d f$ & MS & Number of obs & $=$ & 149 \\
\hline Model & 304.476301 & 3 & 101.4921 & Prob $>F$ & $=$ & 0.0000 \\
\hline Residual & 189.334743 & 145 & 1.30575685 & $\mathrm{R}$-squared & $=$ & 0.6166 \\
\hline Total & 493.811043 & 148 & 3.3365611 & Root MSE & $=$ & 1.1427 \\
\hline
\end{tabular}

\begin{tabular}{r|rrrrrr}
\hline et & Coef. & Std. Err. & $t$ & P $>$ |t| & [95\% Conf. Interval] \\
\hline er & -2.856085 & .4449646 & -6.42 & 0.000 & -3.73554 & -1.976631 \\
logasset & -.8936799 & .0996536 & -8.97 & 0.000 & -1.090641 & -.6967185 \\
logsales & 1.001941 & .1021796 & 9.81 & 0.000 & .7999873 & 1.203895 \\
_cons & 2.750587 & .8168767 & 3.37 & 0.001 & 1.136063 & 4.365111 \\
\hline
\end{tabular}

$\Rightarrow$

$\mathrm{ET}=2.75-2.86 * \mathrm{ER}-0.89 * \log ($ Asset $)+1.00 * \log ($ Sales $)$

With the above-mentioned results, it can be seen that two independent variables Asset (Asset) and ER maintain an inverse relationship with dependent variable ET and have at least $99 \%$ statistical meaning. This shows that OE of logistic JSCs will decrease when it keeps total assets and its financial independence at a high level. This result is not consistent with the initial judgment of the group.

\section{Solvency}

Regarding the solvency of joint - stock companies listed on Vietnam's stock market, our research group uses two common indicators namely Overall ratio and Quick ratio to measure, evaluate, and our team draws the following conclusions.

Firstly, through Table 5, we can see that the order of all surveyed enterprises has completely changed when compared to OE. In more detail, DL1 is a low-performing enterprise, and its asset and equity turnover ratios are significantly smaller than other firms in the same industry. However, this company has sufficient resources to maintain the overall ratio at 72.02 times, which is the highest among all surveyed firms. In contrast, HVN and VIC are two enterprises with a large capital scale and good operating efficiency, but the solvency of these businesses is limited when both ratios are ranked at the last level.

Table 5. Overall ratio

\begin{tabular}{ccccccc}
\hline JSCS & $\mathbf{2 0 1 4}$ & $\mathbf{2 0 1 5}$ & $\mathbf{2 0 1 6}$ & $\mathbf{2 0 1 7}$ & $\mathbf{2 0 1 8}$ & Average \\
\hline 01.DL1 & 5.842 & 9.060 & 34.112 & 169.439 & 141.661 & 72.023 \\
02.PGT & 61.533 & 68.433 & 43.347 & 32.582 & 4.025 & 41.984 \\
03.HMH & 21.033 & 26.170 & 16.623 & 32.103 & 36.246 & 26.435 \\
04.TCO & 38.102 & 24.741 & 18.057 & 14.192 & 21.755 & 23.369 \\
05.CAG & 16.710 & 12.195 & 17.009 & 20.076 & 24.507 & 18.099 \\
06.CLL & 3.985 & 4.458 & 6.896 & 25.520 & 30.494 & 14.271 \\
07.VGP & 4.510 & 24.747 & 18.660 & 1.051 & 0.000 & 9.794 \\
08.NAP & 6.403 & 7.149 & 10.092 & 12.917 & 10.324 & 9.377 \\
09.VSC & 5.913 & 7.062 & 8.818 & 12.457 & 11.546 & 9.159 \\
10.HTV & 4.906 & 8.872 & 9.520 & 6.659 & 6.355 & 7.262 \\
11.BSC & 4.507 & 3.830 & 5.081 & 4.671 & 6.262 & 4.870 \\
12.TTZ & 3.966 & 3.719 & 3.820 & 5.663 & 6.070 & 4.648 \\
13.SFI & 4.619 & 4.451 & 4.815 & 4.008 & 5.089 & 4.596 \\
14.GSP & 6.605 & 5.276 & 4.243 & 4.128 & 2.406 & 4.532 \\
15.GMD & 4.013 & 3.759 & 3.154 & 5.328 & 5.108 & 4.272 \\
16.CDN & 3.645 & 5.575 & 4.632 & 3.090 & 4.042 & 4.197 \\
17.PHP & 3.897 & 3.609 & 4.496 & 4.542 & 3.993 & 4.107 \\
18.MAC & 3.090 & 4.545 & 4.451 & 3.944 & 4.326 & 4.071 \\
19.HAH & 2.516 & 2.369 & 2.491 & 5.403 & 5.450 & 3.646 \\
20.STG & 2.530 & 1.327 & 2.110 & 2.843 & 4.490 & 2.660
\end{tabular}


The Effect of Factors on Operational Efficiency and the Relationship between Operational Efficiency and Solvency of Logistics Joint-Stock Companies

\begin{tabular}{lllllll} 
21.TMS & 3.293 & 2.648 & 2.303 & 2.650 & 2.286 & 2.636 \\
22.HHG & 2.020 & 2.563 & 2.340 & 2.651 & 2.827 & 2.481 \\
23.VNS & 2.171 & 2.083 & 1.967 & 2.497 & 2.661 & 2.276 \\
24.VNL & 2.186 & 2.112 & 2.193 & 2.311 & 2.347 & 2.230 \\
25.PVT & 1.753 & 1.846 & 2.074 & 2.119 & 2.072 & 1.973 \\
26.PRC & 1.868 & 1.811 & 1.695 & 1.863 & 1.775 & 1.802 \\
27.ACV & 1.902 & 1.839 & 0.000 & 2.241 & 2.330 & 1.663 \\
28.VOS & 1.344 & 1.275 & 1.172 & 1.195 & 1.215 & 1.240 \\
29.HVN & 1.185 & 1.177 & 1.230 & 1.272 & 1.330 & 1.239 \\
30.VJC & 1.138 & 1.152 & 1.199 & 1.242 & 1.206 & 1.187 \\
\hline
\end{tabular}

In terms of quick ratios, the order is still unchanged. Enterprises have low operational efficiency will have high solvency and vice versa. Specifically, PGT holds the highest position for quick ratio (36.07 times), followed by DL1 with the second highest solvency at 15.91 times, but the performance of both these businesses is at a low level.

Table 6. Quick ratio

\begin{tabular}{ccccccc}
\hline JSCS & $\mathbf{2 0 1 4}$ & $\mathbf{2 0 1 5}$ & $\mathbf{2 0 1 6}$ & $\mathbf{2 0 1 7}$ & $\mathbf{2 0 1 8}$ & Average \\
\hline 01.PGT & 61.386 & 68.433 & 27.680 & 20.599 & 2.243 & 36.068 \\
02.DL1 & 5.378 & 9.151 & 9.423 & 30.266 & 25.315 & 15.907 \\
03.BSC & 3.392 & 6.087 & 13.228 & 11.270 & 14.157 & 9.627 \\
04.TCO & 7.554 & 7.366 & 11.247 & 6.418 & 9.738 & 8.465 \\
05.HMH & 5.728 & 7.320 & 4.440 & 8.441 & 13.070 & 7.800 \\
06.CAG & 7.068 & 4.711 & 5.925 & 7.422 & 9.392 & 6.904 \\
07.CLL & 0.693 & 2.721 & 4.767 & 10.468 & 13.255 & 6.381 \\
08.HTV & 3.454 & 7.012 & 7.846 & 3.632 & 3.950 & 5.179 \\
09.VGP & 1.761 & 13.535 & 8.838 & 1.036 & 0.000 & 5.034 \\
10.GSP & 5.821 & 4.000 & 3.618 & 3.790 & 2.445 & 3.935 \\
11.VSC & 2.455 & 3.113 & 3.184 & 3.185 & 3.319 & 3.051 \\
12.VNL & 1.835 & 3.060 & 3.294 & 3.244 & 2.691 & 2.825 \\
13.CDN & 1.618 & 4.920 & 3.465 & 1.253 & 2.331 & 2.717 \\
14.PHP & 1.559 & 1.857 & 3.410 & 3.204 & 2.239 & 2.454 \\
15.SFI & 2.176 & 2.302 & 2.904 & 2.252 & 2.376 & 2.402 \\
16.ACV & 1.758 & 2.694 & 0.000 & 3.519 & 4.032 & 2.401 \\
17.NAP & 1.641 & 2.233 & 3.814 & 1.818 & 2.150 & 2.331 \\
18.HAH & 1.863 & 1.772 & 1.590 & 1.786 & 3.137 & 2.030 \\
19.MAC & 1.429 & 2.214 & 2.171 & 1.876 & 2.033 & 1.945 \\
20.PVT & 1.935 & 1.625 & 1.979 & 1.949 & 1.665 & 1.831 \\
21.GMD & 3.870 & 2.161 & 0.537 & 1.261 & 1.010 & 1.768 \\
22.TMS & 1.981 & 2.305 & 1.203 & 1.083 & 1.469 & 1.608 \\
23.STG & 1.965 & 1.122 & 1.011 & 1.106 & 0.659 & 1.173 \\
24.TTZ & 1.209 & 0.765 & 0.913 & 1.116 & 1.165 & 1.034 \\
25.HHG & 0.314 & 1.206 & 0.757 & 1.407 & 1.258 & 0.988 \\
26.VJC & 0.973 & 0.876 & 0.806 & 0.914 & 0.800 & 0.874 \\
27.VOS & 1.161 & 1.059 & 0.758 & 0.619 & 0.665 & 0.852 \\
28.PRC & 0.884 & 0.924 & 0.688 & 0.828 & 0.793 & 0.823 \\
29.VNS & 0.767 & 0.633 & 0.385 & 0.511 & 0.566 & 0.572 \\
30.HVN & 0.577 & 0.584 & 0.617 & 0.476 & 0.486 & 0.548 \\
\hline & & & & & & \\
\hline
\end{tabular}


The Effect of Factors on Operational Efficiency and the Relationship between Operational Efficiency and Solvency of Logistics Joint-Stock Companies

\section{Relationship between operational efficiency and solvency}

After considering both OE and solvency of logistics JSCs listed on the Vietnamese Stocks market, this study draws some findings as follows.

Firstly, there is an inverse correlation between $\mathrm{OE}$ and solvency of enterprises. A business with good performance always has not enough resources to maintain a stable solvency. This is explained by the fact that VNL and PRC are always the two leading companies in terms of operating efficiency, however, they show solvency at a low level. Not only does it occur in small and medium-sized companies, but this relationship also exists in large companies. Through Table 6 and Table 6, despite their largest scale ad high financial independence, HVN and VJC only have enough resources to ensure the overall solvency and cannot guarantee the ability to pay short-term debts.

The results are similar to the results of the previous studies. According to (Kyule, 2015), the solvency of companies was negatively correlated with OE. This has been validated for all surveyed companies by our research team, especially VNL, PRC, HVN, VJC and DL1. In addition, (Raykov, 2017), companies that reduced their solvency and raise more debts would boost their efficiency of the companies' operations. This is a negative correlation.

To strengthen the founded result, our research team used statistical software STATA 15 to model regression with the least squares regression method (OLS). After running model with the dependent variable of (OVERALL) as well as the three independent variables including TAT, ER and ET, the results are expressed in Table 7.

Table 7. Regression OVERALL with TAT, ER and ET

$$
\text { - reg overall tat et er }
$$

\begin{tabular}{|c|c|c|c|c|c|c|}
\hline Source & SS & $d f$ & MS & Number of obs & $=$ & 148 \\
\hline Model & 14934.3589 & 3 & 4978.11962 & Erob > F & $=$ & 0.0000 \\
\hline Residual & 45633.608 & 144 & 316.900055 & R-squared & $=$ & 0.2466 \\
\hline Total & 60567.9669 & 147 & 412.026985 & Root MSE & $=$ & 17.80 \\
\hline
\end{tabular}

\begin{tabular}{r|rrrrrr}
\hline overall & Coef. & Std. Err. & $t$ & P>lt & [95\% Conf. Interval] \\
\hline tat & -12.91052 & 3.461433 & -3.73 & 0.000 & -19.7523 & -6.068733 \\
et & 5.44156 & 1.780232 & 3.06 & 0.003 & 1.922799 & 8.960322 \\
er & 51.77024 & 9.165592 & 5.65 & 0.000 & 33.65376 & 69.88672 \\
_cons & -23.95817 & 7.311551 & -3.28 & 0.001 & -38.41 & -9.506342 \\
\hline
\end{tabular}

\section{OVERALL $=-23.96-12.91 * \mathrm{TAT}+5.44 * \mathrm{ET}+51.77 * \mathrm{ER}$}

Moreover, our research team also used statistical software STATA 15 to run model with the dependent variable of (QUICK) as well as the three independent variables including TAT, ER and ET, the results are expressed in Table 8.

Table 8. Regression QUICK with TAT, ER and ET

\begin{tabular}{|c|c|c|c|c|c|c|}
\hline Source & SS & $d f$ & MS & \multirow{4}{*}{$\begin{array}{l}\text { Number of obs } \\
\text { F(3, } 144) \\
\text { Prob }>\mathrm{F} \\
\text { R-squared } \\
\text { Adj R-squared } \\
\text { Root MSE }\end{array}$} & $=$ & \multirow{4}{*}{$\begin{array}{r}148 \\
13.25 \\
0.0000 \\
0.2163 \\
0.2000 \\
7.6843\end{array}$} \\
\hline Model & 2347.03012 & 3 & 782.343373 & & $=$ & \\
\hline Residual & 8503.0445 & 144 & 59.0489201 & & $=$ & \\
\hline Total & 10850.0746 & 147 & 73.8100314 & & $=$ & \\
\hline quick & Coef. & std. Err. & $\mathrm{t}$ & \multicolumn{2}{|l|}{$\mathrm{P}>|\mathrm{t}|$} & Interval] \\
\hline tat & -4.530797 & 1.494173 & -3.03 & \multicolumn{2}{|l|}{0.003} & -1.577453 \\
\hline et & 1.97917 & .7684602 & 2.58 & \multicolumn{2}{|l|}{0.011} & 3.498089 \\
\hline er & 20.7085 & 3.956447 & 5.23 & 12.88829 & & 28.52872 \\
\hline _cons & -8.992905 & 3.156126 & -2.85 & -15.23123 & & -2.754585 \\
\hline
\end{tabular}




\section{The Effect of Factors on Operational Efficiency and the Relationship between Operational Efficiency and Solvency}

of Logistics Joint-Stock Companies

$\Rightarrow$

QUICK $=-8.99-4.53 *$ TAT $+1.98 *$ ET $+20.71 * E R$

Table 7 and Table 8 show that the independent variable TAT is inversely proportional to both solvency ratios: Overall ratio and Quick ratio and has at least 99\% statistical meaning. This result is consistent with the previous research conclusion of (Raykov, 2017) and (Kyule, 2015). If a logistics company increased the turnover of its total assets to enhance its OE, this firm would have to bear the risk of reducing its solvency. In other words, the more efficient in the use of assets is, the more limited its ability to pay debts and vice versa.

Secondly, equity turnover (ET) and ER are necessary yet sufficient conditions to increase solvency. Generally, there is a direct proportion between ET, ER and solvency; or big scales of capital and highly independent JSCs are premises for the creation of a high solvency. This is proven when two independent variables ET and ER are directly proportional with both solvency ratios and have at least $99 \%$ statistical meaning. However as analyzed above, increasing turnover of the total assets reduced the solvency of the enterprises significantly. For logistics JSCs, despite having a large capital scale and high degree of financial independence, these enterprises allocated a large amount of companies' resources on enhancing OE by promoting total assets turnover. Although the efficiency of operations increases, the solvency decreases due to over-utilized resources. This gives rise to payment risk for these businesses. From the results of qualitative and quantitative approach in thirty logistics JSCs, it can be concluded that high performance can lead to low solvency and vice versa.

Table 9. Hypothesis test's results

\begin{tabular}{|c|c|c|}
\hline Hypothesis & Contents & Results \\
\hline H1 & Scale of company has a positive impact on Operational efficiency & Accepted \\
\hline H2 & Degree of financial independence has a positive impact on \\
& Operational efficiency & Accepted \\
\hline H3 & Total assets has a positive impact on Operational efficiency & Accepted \\
\hline H4 & Total sales has a positive impact on Operational efficiency & Accepted \\
\hline
\end{tabular}

\section{CONCLUSION AND RECOMMENDATION}

By analyzing the relationship between OE and solvency of logistics JSCs listed on the Vietnam Stock market in the 2014-2018 period, this study draws the conclusion that $\mathrm{OE}$ and solvency exist an inversely proportional relationship. In other words, a strong OE possibly causes low solvency and vice versa.

From the above-mentioned results, it is possible to come up with some policy implications for logistics JSCs. Firstly, these surveyed firms should restructure their total assets. This movement aims at controlling assets turnover and raising these companies' solvency. A suitable structure for assets shows a reasonable usage of capital and helps a company save its costs of mobilizing capital and guarantee their solvency. This also means a company should promote mobilized capital for its business operation or expands its scale of capital and assets as well. In other words, a reasonable structure of assets is a necessary condition.

Secondly, low OE firms should raise more debts to balance between their performance and solvency. Raising more debts helps these companies tighten their cost by tax shield and keep their business performance. This would help companies improve their operational activities considerably and stabilize their profitability.

By researching the relation between OE with solvency of logistics JSCs listed on the Vietnam Stock market, this paper contributes both certain theoretical (clarifying their links) and practical content (giving solutions to increase both OE and solvency). However, as the data of these logistics JSCs being are only take from a five-year period, it is not long enough to have a large research sample. A related study in the future may be undertaken including more industries rather than the logistics field only and a study over a longer period of time would give out a more precise prediction the relationship between OE and solvency, and more elements which affect them in companies.

\section{ACKNOWLEDGEMENT}

This research is funded by National Economics University, Hanoi, Vietnam. 


\section{The Effect of Factors on Operational Efficiency and the Relationship between Operational Efficiency and Solvency of Logistics Joint-Stock Companies \\ REFERENCES}

1) Ahmad, R. (2016). A study of relationship between liquidity and profitability of standard charterd bank Pakistan: Analysis of financial statement approach. Global Journal of Management and Business Research.

2) Amer, H. H., Moustafa, W., \& Eldomiaty, T. (2011, June). Determinants of operating efficiency for lowly and highly competitive banks in Egypt. In Cambridge Business and Economics Conference (Vol. 1, pp. 1-35).

3) Beal, V. (2016). Operational Efficiency. cited 30/07/2016 from http://www. webopedia. com/TERM/O/operational_efficiency. html.

4) Bernstein, L.A. (1988). Financial statement analysis, theory, application, and interpretation, Journal of Accounting Research, Vol. 3, 61-80.

5) Burrows, M. (2012). Operational Efficiency-It's not just about Cost Cutting. cited 30/07/2016 from http://www. bsmreview. com/oppseff. shtml.

6) Ehiedu, V. C. (2014). The impact of liquidity on profitability of some selected companies: The financial statement analysis (FSA) approach. Research Journal of Finance and Accounting, 5(5), 81-90.

7) Feng, C. M., \& Wang, R. T. (2000). Performance evaluation for airlines including the consideration of financial ratios. Journal of Air Transport Management, 6(3), 133-142.

8) Gleason, K. C., Mathur, L. K., \& Mathur, I. (2000). The interrelationship between culture, capital structure, and performance: evidence from European retailers. Journal of business research, 50(2), 185-191.

9) Hartman, D. How to Calculate the Maximization of Operational Efficiency. cited 30/07/2016 from http://smallbusiness. chron. com/calculate-maximization-operational-efficiency-35448. html.

10) Höbarth, L. L. (2006). Modeling the relationship between financial indicators and company performance. An empirical study for US-listed companies (Doctoral dissertation, WU Vienna University of Economics and Business).

11) Kokemuller, N. Operational Effectiveness Vs. Strategic Positioning. cited 30/07/2016 from http://www. ehow. com/info_8447934_operational-effectiveness-vs-strategic-positioning. html.

12) Kyule, J. (2015). Impact of Liquidity And Solvency On Financial Performance Of Firms Listed At The Nairobi Securities Exchange. Unpublished MSc Finance Project, University of Nairobi, 6(3), 526-533.

13) Lauterbach, B., \& Vaninsky, A. (1999). Ownership structure and firm performance: Evidence from Israel. Journal of Management and Governance, 3(2), 189-201.

14) Memon, F., Bhutto, N. A., \& Abbas, G. (2012). Capital structure and firm performance: A case of textile sector of Pakistan. Asian Journal of Business and Management Sciences, 1(9), 9-15.

15) Mudambi, R., \& Nicosia, C. (1998). Ownership structure and firm performance: evidence from the UK financial services industry. Applied Financial Economics, 8(2), 175-180.

16) Nguyen Van Cong, Business Operation Analysis Textbook, National Economics Publisher, Hanoi, 2009.

17) Onaolapo, A. A., \& Kajola, S. O. (2010). Capital structure and firm performance: Evidence from Nigeria. European Journal of Economics, Finance and Administrative Sciences, 25(1), 70-82.

18) Pentikäinen, T. (1952). On the net retention and solvency of insurance companies. Scandinavian Actuarial Journal, 1952(12), 71-92.

19) Raykov, E. (2017). The liquidity-profitability trade-off in Bulgaria in terms of the changed financial management functions during crisis. Management: journal of contemporary management issues, 22(1), 135-156.

20) Sandström, A. (2007). Solvency-a historical review and some pragmatic solutions. Mitteilungen der Schweizerischen Aktuarvereinigung, 1, 11-34

21) Siminica, M., Circiumaru, D., \& Simion, D. (2012). The correlation between the return on assets and the measures of financial balance for Romanian companies. International journal of mathematical models and methods in applied sciences, 6(2), 232-253.

22) Tzelepis, D., \& Skuras, D. (2004). The effects of regional capital subsidies on firm performance: an empirical study. Journal of Small Business and Enterprise Development.

23) Varadan S., "What Is the Meaning of Operational Efficiency?", 2016, cited 30/07/2016 from http://www.ehow.com/about_6495198_meaning-operational-efficiency_html>.

24) Zeitun, R., \& Tian, G. G. (2007). Does ownership affect a firm's performance and default risk in Jordan?. Corporate Governance: The international journal of business in society. 